\title{
Michał Wyszyński
}

\section{Geneza podstawowych elementów obowiazującego dziś kanonicznego prawa zwyczajowego}

Prawo Kanoniczne : kwartalnik prawno-historyczny 2/1-2, 301-330

1959

Artykuł został zdigitalizowany i opracowany do udostępnienia w internecie przez Muzeum Historii Polski w ramach prac podejmowanych na rzecz zapewnienia otwartego, powszechnego i trwałego dostępu do polskiego dorobku naukowego i kulturalnego. Artykuł jest umieszczony w kolekcji cyfrowej bazhum.muzhp.pl, gromadzącej zawartość polskich czasopism humanistycznych i społecznych.

Tekst jest udostępniony do wykorzystania w ramach dozwolonego użytku. 
Ks. MICHAE W Y S Z Y Ń S K I

\section{GENEZA PODSTAWOWYCH ELEMENTOW OBOWIĄZUJĄCEGO DZIS̃ KANONICZNEGO PRAWA ZWYCZAJOWEGO}

Jeżeli się twierdzi, że przy rozpatrywaniu nowokodeksowej problematyki nie sposób dokonać jakiegoś głębszego badania bez znajomości przedkodeksowych rozwiązań w lanym przedmiocie, to cóż dopiero mówić, gdy idzie o taki kluczowy temat, jak zwyczaj i prawo zwyczajowe, - temat, o którym się wie, że na przestrzeni całej historii prawa kanonicznego budził zawsze niezwykłe zainteresowanie u prawników, zarówno teoretyków jak i praktyków. Że to zainteresowanie nie zmniejszyło się po wejściu w życie nowego kodeksu, wystarczy przeglądnąć choćby wykaz prac podanych przez Michielsa ${ }^{1}$.

Zagadnienie, któremu zamierzamy tutaj poświęcić kilka uwag, należy do zasadniczych. Wysuwała je stale nauka przedkodeksowa, wysuwa i wyisuwać będzie pokodeksowa. Jeżeli je idzisiaj wzmawiamy, to nie na to, aby przedstawić szczegółowo całokształt dotychczasowych rozwiązań w tym przedmiocie, ale na to, aby stwierdzić, czy i o ile na obecnym etapie badań naukowych owe rozwiązania dadzą się utrzymać i czy nie naley ich zmienić2.

1 M i chie $1 \mathrm{~s}$ G., Normae generales iuris canonici, Parisiis-Romae $19492,2,1-3$.

2 Literatura przedmiotu: a) dawniejsza zob.: Brie S. Die Lehre vom Gewohnheitsrecht, Erster Theil Geschichtliche Grundlegung Breslau 1809; 
Zacznijmy od stwierdzenia, że od idawien dawna obiegało i tu i ówdzie obiega jeszcze dzisiaj w nauce przeświadczenie, iż zarówno pojęcie zwyczaju jak i prawa zwyczajowego wzią Kościół z prawa rzymskiepo. Oczywiście tego rodzaju przeświadczenie implikuje, że Rzymianie musieli już mieć wyrobione pojęcie o tych dwóch zródłach. Czy są na to dowody? Owszem - odpowiada się - choćby n.p. fragment $z$ justyniańskich Instytucji 1, 2, 3: Constat autem ius nostrum

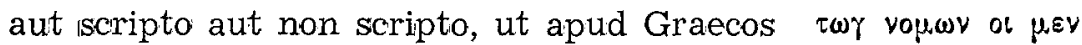

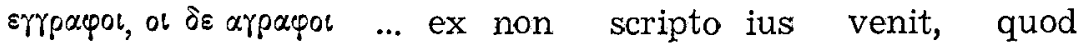
usus comprobavit, nam diuturni mores consensu comprobati legem imitantur, albo $\mathrm{z}$ Digestów I ks. 3 tytuł: De legibus senatusque consultis et longa consuetudine, $z$ których to źródeł wynika niewątpliwie, że consuetudo była w czasach justyniańskich zaliczana do źródeł niepisanego prawa rzymskiego. Jeśli zaś idzie o odpowiedź na pytania dalsze, a więc: na czym zasadza się struktura tego źródła prawnego, jaka jego skuteczność, odpowiadało się dawniej i tu i ówdzie odpowiada się dzisiaj, że można ją znaleźć w materiale źróldłowym, zawartym $w$ zbiorach justyniańskich, a sięgającym jeżeli nie czasów najdawniejszych, to $\mathrm{w}$ każdym razie klasycznego prawa rzymskiego.

Tymczasem wyniki niedawnych badań takich autorów, jak Steinwenter ${ }^{3}$, Schulz ${ }^{4}$, Lombardi ${ }^{5}$, Kaser ${ }^{6}$, i Gaudemet ${ }^{7}$, usta-

M i chie Is, Normae 1-2; b) nowsza zob.: Kas e r M., Mores maiorum und Gewohnheitsrecht, SZ. 59 (1939) 52 nst.; Tenże Das römische Privatrecht München (1955), 173; G a u dem et J., La coutume au Bas Empire, Labeo 2 (1956) 2, 147-159; Tenże La formation du droit seculier et du droit de $l$ Eglise au IV et $V$ siécles Sirey 1957; $\mathrm{M}$ i c h ie l s Normae; 2-3.

3 Steinwenter A., Zur Lehre vom Gewohnheitsrechte, Studi Bonfante II, Milano 1929, 419-440.

4 S chuz F., Prinzipien des römischen Rechts 1934, 147 nst.; Tenże Principles Roman Law 1936 III „Isolation”.

5 Lombardi G., Sul titulo "Quae sit longa consuetudo" (8.52[53]) nel Codice Giustinianeo, Roma, Studia et Documenta XVIII, 1952, 21 nst. 
liły, że do czasów poklasycznych prawo rzymskie nie wiédziano, iż zwyczaj może wytworzyć prawo zwyczajowe. Ich zdaniem, przytłaczającą większość materiału źródłowego z czasów przedpoklasycznych należy odnieść tylko do samego zwyczaju, przy czym nie ulega wątpliwości, że Rzymianie mimo niestałości nazw dla zwyczaju (usus, mores, consuetudo, vetustas) i mimo zmiennego posługiwania się tymi nazwami (raz $\mathrm{w}$ znaczeniu przyczyny, idrugi raz $\mathrm{w}$ znaczeniu skutku), zdawali sobie dobrze sprawę, iż istota jego zasadza się na powtarzających się tych samych zewnętrznych czynnościach danej społeczności.

Myliłby się, kto by sądził, że owo ujęcie prawnej struktury zwyczaju było samodzielnym dorobkiem myśli rzymskiej. Korzeniami swymi sięga ono niewątpliwie czasów i ludów dawniejszych. N.p. Hellebranldt w swoich studiach nad stosun-

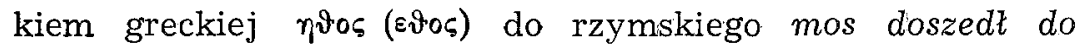
następującego poglądu ${ }^{8}$ : Wyraz rios - to $\mathrm{z}$ początku vox media, czyli pojęcie neutralne, nie wkraczające w żadne etyczne wartościowanie zewnętrznego zachowania się dawnej wspólnoty luidzkiej. Natomiast wyraz $\varepsilon \mathfrak{0} \circ$, etymologicznie wy-

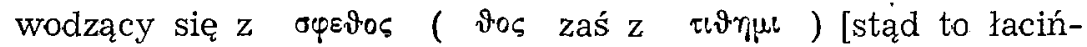
skie suescere i suetudo], - to juz nie vox media, ale kto wie, czy nie najdawniejszy kwalifikator stałego $w$ danym miejscu bytowania wspólnoty ludzkiej, zwanej najogólniej xocvov $\alpha$ Łacińskim odpowiednikiem takiego etosu byłyby wyrazy habere, habitare, habitus. Tak — powtarzam - miało być $\mathrm{z}$ początku. Z czasem ów neutralny wyraz r $^{\circ}$ os staje się w mentalności greckiej kwalifikatorem etycznego nakazu, wypływającego właśnie $z$ ldanego stanu faktycznego, oznaczonego przed chwilą jako $\varepsilon \vartheta \varsigma s$. Ten przyczynowy związek między oboma etosami został ujęty przez Platona w maksy-

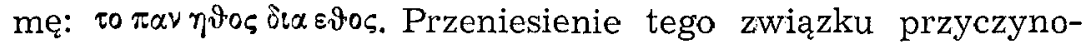
wego ze sfery etycznej do prawnej miało właśnie dać w wy-

\footnotetext{
$6 \mathrm{~K}$ a s er M., j. w.

7 G a d demet J., j. w.

$8 \mathrm{He}$ ellebrand W., Ein Beitrag zur Problematik - matrimonium und mos - SZ 70 (1953), 256 nst.
} 
niku początek prawu zwyczajowemu, czyli vopol $\delta\left\llcorner\alpha \varepsilon \vartheta \gamma_{\text {l. }}\right.$ Co się zaś tyczy lacińskiego mos ( $z$ greckiego paroual $=$ dażyć, starosł. myślić), to zdaniem Hellebranda nie używano w Rzymie tego wyrazu na oznaczenie zewnętrznej strony stałego zachowywania się wspólnoty ludzkiej, ale określano nim raczej nakaz etyczny opierający się na doraźnym jakimś zdarzeniu, n.p. na wyrażonej woli bogów, woli ojców (mores maiorum) i tym właśnie należy tłumaczyć - twierdzi dalej Hellebrand - dlaczego Rzymienie nie zmieniali swoich mores na ustawy, jak to robili Grecy, ale pozwalali im istnieć dalej obok prawa. Oczywiście tego rodzaju pogląd nie wyklucza, aby wyrazu mos nie używano także do oznaczania faktycznej strony prawa zwyczajowego. Owszem spotykamy w źróldłach wyrażenia: ius moribus et consuetudine inductum, moribus constitutum, a więc takie, które wskazują, że prawo zwyczajowe rodzi się ze zwyczaju. Czy $w$ tych wyrażeniach mamy do czynienia $z$ odwzorowaniem przytoczonej wyżej platońskiej maksymy, nie będziemy się wdawali $w$ rozstrzyganie tego pytania.

Przejdźmy z kolei do strony konstytutywnej zaistnienia prawa zwyczajowego. Jak wiadomo, wyrażenia constituere, inducere, w połączeniu z lex wskazują na pochodzenie jakiejś ustawy z głosowania, wzgl. zgody ludu rzymskiego. W zastosowaniu zaś do prawa zwyczajowego każą nam te wyrażenia dopatrywać się także ustawodawczej woli ludu, ale objawionej nie przez głosowanie, lecz przez fakt powtarzającego się wykonywania tych samych czynności (nam diuturni mores consensu utentium comprobati legem imitantur I. 1,2, 9 : nam quild interest suffragio populus voluntatem suam declaret an rebus ipsis et factis D. 1, 3, 32), czyli jak się wyraża Ulpian lib. sing. reg. Praem. $\S 4$ tacito consensu populi. Ale stweirdzając w źródłach tego rodzaju pogląd, tym samym nie rozstrzygnęliśmy jeszcze, że ten drugi konstytutywny element prawa zwyczajowego, t.j. cicha zgoda był wytworem myśli rzymskiej. A tak właśnie niegdyś głoszono i dzisiaj jeszcze tu i ówidzie się głosi. Zasadność takiego poglądu zaatakowali w ostatnich czasach Steinwenter, Schulz, Lombardi, Kaser i Gaudemet, 
wykazując $z$ jednej istrony niehistoryczność takiej władzy ustawodawczej u ludu rzymskiego (w ustroju republikańskim inicjatywe ustawodawczą miał magistratus, a senat ją zatwierdzal), $z$ drugiej zaś zapożyczenie wymogu cichej zgody $z$ myśli greckiej.

Po omówieniu tych obu konstytutywnych elementów prawa zwyczajowego przechodzi się zwykle w systematyce prawniczej do koniecznych warunków zaistnienia danego prawa zwyczajowego i do skuteczności jego. Mówiąc o warunkach, ma się na myśli między innymi takie zagadnienia jak czas trwania, czy do zaistnienia trzeba działania całej spoleczności, czy też wystarczy przez analogię do lex tylko jej wiekszość, czy część, n.p. provinciae, regionis, municipii. Lecz tę problematykę przesuwamy $w$ naszych dociekaniach na plan dalszy, natomiast w tym miejscu skupimy uwagę nad najistotniejszym $z$ punktu widzenia teorii prawa warunkiem, tj. nad racjonalnością.

Zacznijmy od materiału źróldłowego. Oto on: ratio, quae consuetudinem suasit custodienda est (C. 8, 52, 1); consuetudinis ususque longaevi non vitis auctoritas est, vero non usque adeo sui valitura momento, ut rationem vincat aut legem (ibid. 2 Constanitinus 319); quod vero contra rationem iuris receptum est, non est producendum ald consequentias (D. 1, 3, 14); ius singulare est, quod contra tenorem rationis propter aliquam utilitatem auctoritate constituentium introductum est (ibid. 16); quod non ratione introductum, sed errore primum, deinde consuetudine obtentum est, in aliis similibuis non obtinet (ibid. 39).

Że nieodzowna jest owa racjonalność do zaistnienia prawa zwyczajowego, podobnie jak i do każdego prawa pisanego, wydaje się wynikać z przytoczonych źródeł już na pierwszy rzut oka. Tymczasem ostrożny Brie ${ }^{9}$ zauważył, że źródła D. $1,3,39$ i 14 mówią tylko o niedopuszczeniu do analogicznego rozszerzania irracjonalnego prawa zwyczajowego, a przytoczony wyżej reskrypt Konistantyna wspomina wprawdzie

9 B rie S., Die Lehre, 23 nst.

Prawo Kanoniczne -20 
o potrzebie racjonalności, ale nie określa bliżej, o jaką to racjonalność chodzi, czy o tak zwaną ratio iuris, czy ratio utilitatis. Na pytanie zaś, co to są, względnie czym się różnią te obydwie rationes, określił on, że ratio iuris - to mówiąc językiem Voigta, „ordnende Potenz innerhalb des Rechtsgebietes", czyli porządkująca siła rozumu, występująca w sferze prawnej, zarówno przy powstawaniu prawa pisanego jak i prawa zwyczajowego ,a wywodząca się z samej rozumnej natury ludzkiej. $\mathrm{Na}$ potwierdzenie takiego właśnie ujęcia, przytoczył on $z$ Cicerona de Inv. II cap. $22 \S 65,53 \S 160$ i $z$ Tertuliana de Corona militis c. 2, 4, 5, 7. Nie naruszając w niczym dowodowej siły powyższego poglądu Brie'go, pozwolimy sobie ldodać od siebie, iż powiedzenie Cicerona: Initium ergo eius (iuris) ab natura ductum videtur, a Tertuliana: Videris unde auctoritas moris... Plane, ut ratio quaerenda sit, zaczerpnięte zostały, kto wie, czy nie zmyśli stoickiej i przeniesione na grunt rzymski ${ }^{10}$. Co więcej. Przy psychologicznym stoickim moniźmie, według którego rozum wykonywał funkcje nie tylko poznawcze, ale i napierające do skutecznego działania (ôpun), stawałoby się zrozumiałe, dlaczego w źródłach rzymskich nie wymienia się woli jako bezpośredniej przyczyny sprawczej danego prawa oraz dlaczego między postulatami zaistnienia prawa zwyczajowego nie wspomina się t.zw. opinionis necessitatis, względnie animi se obligandi. Oba te bowiem elementy tkwily według ówczesnych psychologicznych poglądów immanentnie już $w$ samym rozumie ${ }^{11}$. Co się zaś tyczy pojęcia rationis utilitatis, to wydaje się, iż treść jego można sprowadzić do zamiaru uzyskania przez dane prawo ustawowe, względnie zwyczajowe, jakiegoś konkretnego dobra, oczywiście społecznego. Przy takim ujęciu różnica między powyższymi obydwiema kategoriami racji polegała by na tym,

$10 \mathrm{~K}$ a se r, Mores maiorum, 97 twierdzi, że wypowiedzenia Tertuliana nie mają charakteru ściśle prawniczego.

11 Zob. Wyszyński M., Metus maioris malitatis $w$ prawie rzymskim, Zeszyty naukowe Uniwersytetu Wroclawskiego SA, Nr 6 (1956), 41; Tenże Quamvis si liberum esset noluissem, tamen coactus volui, Symbolae R. Taubenschlag dedicatae III (EOS XLVIII, 3) 1957, 480 nst. 
że gdy ratio iuris swymi korzeniami tkwi bezpośrednio w rozumnej naturze ludzkiej, to ratio utilitatis opiera się na konkretnych spolecznych postulatach bieżącego życia.

$\mathrm{Na}$ koniec zostało nam jeszcze do rozpatrzenia zagadnienie stosunku rzymskiego prawa zwyczajowego do prawa pisanego, a ściślej mówiąc do lex. Mówimy, że w stosunku do lex, gdyż - jak słusznie zauważył Brie ${ }^{12}$ - ta właśnie pierwotna forma ustawy rzymskiej, której główną rolę pełnił populus Romanus, stała się z czasem w mentalności rzymskiej prototypem i miarą każdego źróldła prawnego pisanego i niepisanego, nawet wtedy, kiedy już lud rzymski został wyłączony od brania udziału we władzy ustawodawczej, względnie, kieddy tę władzę swoją spełniał już tylko fikcyjnie n.p. poprzez senat i cesarzy. Otóż okazuje ısię, że ta sama lex stała się u Rzymian także miarą przy „wartościowaniu" consuetudinis jako źródło prawnego.

Zacznijmy od przypaldku, gdy consuetudo zostanie objęta prawem pisanym. Fragment z D. 1, 3, 37 tak mówi: Si de interpretatione legis quaeratur, in primis inspiciendum est, quo iure civitas retro in eiusdem casibus usa fuisset: optima enim est legum interpres consuetudo. Czyli z tytułu czasowego pierwszeństwa wypadnie wtedy dla consuetudo tylko rola rozstrzygającego czynnika interpretacyjnego przy zaistnieniu jakiejś wątpliwości w nowopowstałej lex - rola, wynikająca ze stosunku określonego później nazwą consuetudinis secundum legem.

Już większą - bo zastępczą względnie subsydiarną - rolę wyznaczyło prawo rzymskie dla consuetudo w przypadku życiowym, który nie został jeszcze objęty prawem pisanym: In quibus causis scriptis legibus non utimur, id custodire oportet, quod moribus et consuetudine inductum est: et si qua in re hoc deficeret, tunc quod proximum ei est: si nec id quidem appareat, tunc ius, quo urbs Roma utitur, servari oportet. (D. 1, 3, 32). Jak wiadomo, tego rodzaju rola prawa zwyczajnego otrzymała $\mathrm{z}$ czasem nazwę stosunku consuetudinis praeter legem

12 B rie, Die Lehre, 34 nst. 
Stajemy wreszcie przeld pytaniem, co się działo $\mathrm{w}$ przypadku zaistnienia antynomii, czyli gdy consuetudo stanęła contra legem i odwrotnie. Otóż, gdyby consuetudo co do swojej skuteczności była zrównana $\mathrm{z}$ lex, powinny by oba powyższe antynomiczne przypadki być rozstrzygnięte $w$ myśl zasady lex posterior derogat priori. Że $w$ tym ldrugim przypadku antynomia odpadała, rzecz ta nie ulega żadnemu wątpieniu. Natomiast przy rozpatrywaniu przypadku pierwszego stwierdzić trzeba, że dawniejsza nauka $z$ Brie'm ${ }^{13}$ na czele wstrzymywała się od zajęcia $w$ tej sprawie zdecydowanego stanowiska, a to $z$ powodu rzekomej sprzeczności między następującymi źródłami: Consuetudinis ususque longaevi non vilis auctoritas est, verum non usque adeo sui valitura momento, ut aut rationem vincat aut legem (C. 8, 52, 2 Constantinus 319) i ...quare rectissime etiam illud receptum est, ut leges non solum suffragio legislatoris, sed etiam tacito consensu imnium per ldesuetudinem abrogentur (D. 1, 3, 32 Iulianus); ea vero, quae ipsa sibi quaeque civitas constituit, saepe mutari solent vel tacito consensu populi vel alia postea lege lata (Inst. 1, 2, 11). Tymczasem najnowsza nauka doszła do przeświadczenia, że tej kolizji między owymi źródłami nie ma, gdyż: $1^{0}$ treść przytoczonego fragmentu Juliana, interpolowana przez justyniańskich kompilatów, odpowiada ściśle treści fragmentu $z$ Inst. 1, 2, 11 - treści zawierającej wyraźnie zasadę, iż za Justyniana consuetuido co do swej skuteczności zrównana $z$ lex mogła przeciwne sobie prawo ustawnicze znieść, a to na zasadzie lex posterior derogat priori; $2^{0}$ natomiast o 200 lat wcześniejszy wyżej przytoczony reskrypt Konstantyna odnosi się do konkretnego przypadku, mianowicie do stosunku partykularnej consuetudinis do ogólnie obowiązującej lex i stwierldza, że tego rodzaju consuetudo nie może naruszyć prawa ustawniczego ${ }^{14}$.

13 Tamże 33 nst.

14 Zob.: Lom bardi, Sul titulo, 21 nst; $\mathrm{K}$ a se r, Mores maiorum, 66, $102 \mathrm{nst}$; Gaudem et, La formation, 113 nst; Tenże La coutume, 149. 
Zbierając tedy razem wszyistko, co dotąd o rzymskiej consuetudo powiedzieliśmy, nie sposób już dzisiaj twierdzić, jak to czyniła dawniejsza nauka - że Rzymianie od najdawniejszych czasów swojej historii mieli wyrobione pojęcie o consuetudo jako prawnym źródle. Slady takiego pojęcia spotykamy $u$ nich dopiero $w$ czasach poklasycznych $i$ to nie jako dorobek własnej myśli prawniczej, lecz jako przejątek z wcześniej rozwiniętej myśli greckiej. Mimo stwierdzonego faktu, iż źródła prawne $\mathrm{z}$ czasów justyniańskich poruszają prawie że wszystkie podstawowe elementy consuetudinis jako prawa zwyczajowego, nie można jeszcze mówić, iż Rzymianie za Justyniana mieli już $w$ calej pełni rozwiniętą teorię tego bądź co bądź skomplikowanego źródła prawnego. Celowo ten ostatni prawno-historyczny fakt tutaj podkreślamy, bo chcemy w tym miejscu zaznaczyć, iź właśnie on wyznaczać nam będzie dalsze badanie nad genezą głównych elementów kanonicznego prawa zwyczajowego.

Gdy więc w świetle powyższych wyników dotychczasowych naszych dociekań przychodzi odpowiedzieć na glówne pytanie, czy Kościół swoje pojęcie zwyczaju i prawa zwyczajowego wziął z prawa rzymskiego, stwierdzić musimy, że odpowiedź nasza będzie złożona. Oto ona:

Przelde wszystkim należy sobie zdać sprawę, że do czasów Tertuliana nie posiadamy $w$ tym przedmiocie żadnego kanonicznego źródła. Jeżeli dawniejsza nauka $w$ ślad za prawem rzymskim domniewała się dla tego okresu także bogatego, bo początkowego, rozwoju zarówno zwyczajów jak i prawa zwyczajowego w Kościele, to dzisiejszy stan badań nakazywałby wstrzemięźliwość odnośnie prawa zwyczajowego a dopuszczałby możliwość odnośnie zwyczaju.

Co się zaś tyczy źródeł Tertuliańskich, to przytacza się następujące: $z$ de Corona cap. 2. - Videris unde auctoritas moris, te qua nunc maxime quaeritur... Plane, ut ratio quaerenda sit, sed salva observatione... quo magis observes, cum fueris etiam de ratione securus; cap. 4-Consuetudo autem etiam in civilibus rebus pro lege suscipitur, cum deficit lex; cap. 5 - Maior efficitur ratio Christianorum, cum illas 
etiam natura defendit; $z$ de Virginibus velandis cap. 1 , - hoc exigere veritatem, cui nemo prescribere potest, non spatium temporum, non patrocinia personarum, non privilegium regionum. Ex his enim fere cansuetuldo initum ab aliqua ignorantia vel simplicitate sortita in usum per successionem corroboratur et ita adversus veritatem vindicatur. Sed dominus noster Christus veritatem, non consuetudinem cognominavit. $\mathrm{Z}$ tych więc źródeł wynika: $1^{0}$ że podobnie jak w sprawach cywilnych bierze się consuetudo praeter legem pro lege, tak samo dzieje się i w Kościele, $2^{0}$ że $\mathrm{z}$ ldwóch rodzaji consuetudinis jeden biorący swój początek z rozumnej natury ludzkiej, a drugi $z$ ignorancji względnie $z$ braku należytego zrozumienia rzeczy, wybrał Kościół rodzaj pierwszy, tymbardziej, gdy do prawa naturalnego idoszła jeszcze objawiona Chrystusowa prawda; $3^{0}$ że ratio, wywodząca się z rozumnej natury ludzkiej i prawdy Chrystusowej jest nieodzowna do zaistnienia observationum christianarum. Porównując te chrześciańskie dane $z$ danymi rzymskiego prawa zwyczajowego, stwierdzić należy, że poza jedną cechą różniczkującą, t.j. Chrystusową prawdą pokrywają się ze sobą. Oczywiście nie można zdaniem naszym z powyższego spostrzeżenia wyprowadzać wniosku, iż Kościól swój pogląd na zwyczaj i prawo zwyczajowe sformułował sobie dopiero na poglądzie rzymskim. Tu mogły odldziałać także bezpośrednie wplywy greckie.

Przechodząc do czasów potertuliańskich, każą nam wyniki badań Lombardi'ego zatrzymać się nad Constitutio Antoniana (212) i przytoczonym wyżej reskryptem Konstantyna z r. 319. Przyjąwszy bowiem za tym autorem, że zagaldnienie prawa zwyczajowego wystąpiło najsilniej po roku 212, nie możemy przyjąć, aby ta data odbiła się również na rozwoju kościelnego prawa zwyczajowego. Co innego, gdy idzie o czasy po edykcie mediolańskim, kiedy to Kościół, jak slusznie zauważył Gaudemet' ${ }^{15}$, zaczął na szerszą skalę wyodrębniać właśnie źródła prawne, między nimi także consuetudines ecclesiasticas. Że Kościół do zaistnienia swojej consuetudinis wymagał tych sa-

15 G a u d emet, La formation, 173 nst. 
mych elementów konstytutywnych, których żądało prawo rzymskie, oraz że tę samą przypisywał jej skuteczność, można się tego tylko domniemywać.

Przejdźmy z kolei ıdo czasów następnych, czyli do 500 lecia, które, jak wiadomo przegradza na Zachodzie justyniańskie Zbiory od początków szkół glossatorskich i to zarówno prawa rzymiskiego jak i kanonicznego.

a) Zacznijmy od stwierdzenia, iż według ostatnich badań nie da się żadną miarą utrzymać lansowanego niegdyś poglądu, że na przestrzeni tego 500 lecia studiowano materiał źródłowy, nagromadzony w justyniańskich Zbiorach. Przeciwnie. Od czasów Grzegorza W. do 11 w. były Digesty w zupełnym zapomnieniu. Jeżeli się tu i ówdzie pojawiły Instytucje, Kodeks i Nowele, to nie w całości, ale w wyjątkach. Również na wzór obiegających $w$ tym okresie czasu rozlicznych encyklopedycznych zbiorów ułożono dla potrzeb kościelnych t.zw. Lex romana caconice compta ${ }^{16}$.

Mówiąc o tym, nie zamierzamy bynajmniej twierldzić, że w następstwie powyższych faktów historycznych powinno by się przyjąć, iż uległy zapomnieniu wszystkie instytucje prawa rzymskiego i kanonicznego, a zwłaszcza tak podstawowe i żywotne, jak zwyczaj i prawo zwyczajowe. Dowodem następujące źródła: Grzegorz W. - Nos consuetudinem, tamen contra fidem nihil usurpare dignoscitur, immotam permanere concedimus; Izydor Sywilski - Mos est... lex non scripta... consuetudo est ius quoddam moribus constitutum, quod pro lege suscipitur, cum deficit lex... vocatur consuetudo, quia in communi est usu ...usus auctoritati cedat, pravum usum lex et ratio vincat; Mikołaj I - Consuetudines, si illis canonica non

16 Zob: Genzmer, Die justinianische Kodifikation und die Glossatoren, Atti del Congresso Internazionale di Diritto Romano (1933) XI-V. I, Romae 347-430; K uttner, Zur neuesten Glossatorenforschung, Studia et Documenta 1940, VI 2, 275 nst. 
obsistit auctoritas, pro qua eis obviare debeamus... nihil iudicamus eis debere vel posse resisti; Leon IX - Scit sancta Romana Ecclesia, quod nihil obsunt saluti credentium diversae pro loco et tempore consuetudines, si illis canonica non obsistat auctoritas, pro qua eis obviare debeamus ${ }^{17}$. Oczywiście, spośród tych źródel wysuwają się na czoło przede wszystkim Izydorowe, choćby przez swoją ilość skrótowych ujęć zwyczaju i prawa zwyczajowego, - ujęć tkwiących swymi korzeniami głównie $w$ justyniańskich Instytucjach, Digestach i Kodeksie. Są one składową częścią tych pojęć, które Izydor uznał za stosowne umieścić na temat prawa wogóle, a prawa rzymskiego $\mathrm{w}$ iszczególności. Jaką drogą dostały się elementy rzymskiego prawa zwyczajowego do Izydora, sprawę te zostawiamy na boku. Natomiast nie możemy pominąć faktu, że Izydor omawiając stosunek consuetudinis contra legem ująl go po myśli wyżej przytoczonej konstytucji Konstantyna, a nie - jakby to wynikało $z$ ostatnich baidań - według podanych wyżej Inst 1, 2, -- i D. 1, 3, 32. Czymżesz tłumaczyć to prawno-historyczne zjawisko? Zdaniem naszym możnaby przyjąć, że stanowisko zajęte przez Justyniana $w$ tych obu fragmentach nie zostało w tym czasie przyjęte na Zachodzie. Kiedy konstytucja Konstantyna została kanonizowana przez najwyższe czynniki kościelne, trudno dociec. Nie wykluczone, że tego aktu kanonizacyjnego dokonali Mikołaj I i Leon IX właśnie w przytoczonych przed chwilą dekretałach.

$\mathrm{Na}$ tym ostatnim spostrzeżeniu zamykamy okres 500-lecia i przechoidzimy do Dekretu Gracjana.

b) Nie tu miejsce na omawianie tego wielkiego pomnika w historycznym rozwoju prawa kanonicznego. Co się zaś tyczy jego stanowiska wobec podstawowych elementów zwyczaju i prawia zwyczajowego, to w nauce obiega dotąd przeświadczenie, że poza zebraniem wyżej przytoczonych źródeł kanonistycznych i niektórych rzymskich, skrótowo i często anonimowo przekazywanych — jak widzieliş́my u Izydora — przez wcześ-

17 Powyższe źródła przytaczamy z Dekretu Gracjana, wydanego przez Friedberga. 
niejsze zbiory prawa kanonicznego, nic więcej nie zawiera ${ }^{18}$. Czy osąd ten nie jest za ostry? Pomijamy w Dekrecie Gracjana bogatszy ukłald treści $w$ porównaniu ze zbiorami wcześniejszymi. Podnosimy natomiast, że zadaniem Gracjana była nie tylko Concordia discordantium canonum, ale i stworzenie prawnej podstawy do realizacji gregoriańskich reform ${ }^{19}$. Stąd nie łdziwi nas, dlaczeg autor Dekretu przy omawianiu w swoich diktach zwyczaju i prawa zwyczajowego ograniczył się tylko do wstępnych obiegowych określeń i nie przeszedł do systematyki prawno-teoretycznych zagadnień. Jego interesowały dwa aktualne cele: $1^{0}$ wykazać nadrzędność Bożego prawa naturalnego i objawionego nad wszelkim prawem pozytywnym ludzkim, oraz kościelnego nald świeckim; $2^{0}$ uzasadnić, że $\mathrm{w}$ przypadku zaistniałej sprzeczności między prawem ustawniczym i zwyczajowym, to drugie traci swoja skuteczność i że podobnie przy zbiegu dwóch praw zwyczajowych partykularne musi ustąpić przed ogólnym. Że w tych dwóch ostatnich przypadkach chodziło Gracjanowi o poldkreślenie centralnej władzy papieskiej, świadczą następujące jego dicta: Moribus et decretis Romanorum Pontificum constitutiones contrariae eisse non possunt (c. 4 Dist. X); Statutis Pontificum consuetudo cuiusquam refragari non potest (c. 2 Dist. XI); A consuetudine Romanae Ecclesiae membris dissentire non licet (c. 3 Dist. XI).

c) Przechodząc $z$ kolei do idekretystów, stajemy tym samym u początków nauki kanonistycznej, podobnie jak przez glossatorów wkracza się w początki nauki prawa rzymskiego. Myliłby się, ktoby u pierwszych pokoleń dekretystów i glossatorów chcial szukać już jakichś prawno-teoretycznych uogólnień. Po 500-letnim naukowym milczeniu zarówno pierwsi jak i drudzy musieli zaczynać od nowa, t.j. od opanowywania materiału źródłowego, usuwania w nim napotykanych sprzeczności i szkicowania w summach względnie traktatach najogólniejszych zagadnień teoretycznych. Oczywiście wszystko to odbywało się

18 Zob. B r i e, Die Lehre, 61, 79.

19 Zob. Vetulani A., Dekret Gracjana $i$ pierwsi dekretyści. $w$ świetle nowego źródta, Wrocław-Kraków 1955, 1-50. 
według obowiązujących wtedy metod scholastycznych ${ }^{20}$. Jeśli idzie o stosunek obu tych szkól, to nie układał się on już tak jak $\mathrm{W}$ okresie przedjustyniańskim, kiedy, prawo rzymskie kończyło swój rozwój, a zaczynało zdecydowany start prawo kanoniczne. Teraz dekretyści szli równo z glossatorami, z tym, że gdy kanonistyka wkroczywszy w swój klasyczny okres zasilała się wciąż nowym prawem i problematyką, to nauka prawa rzymskiego pozbawiona dalszego doplywu ustawodawczego, musiała siłą rzeczy zejść do roli najpierw przedmiotu historycznego, by dopiero później zacząć szukać dróg ido nawiązania kontaktu z potrzebami bieżącego życia. Stąd zrozumiałe, dlaczego $z$ początku nie szkoły glossatorskie iszukały zapożyczań u kanonistyki, ale odwrotnie kanoniści u legistów.

Gdy więc w świetle powyższych założeń przychodzi nam ocenić dorobek naukowy ldekretystów w sprawie kanonicznego prawa zwyczajowego, musimy za Brie'em ${ }^{21}$ powiedzieć, że był on niewielki. A to dlatego, że mógł się on z początku obracać jedynie koło Dekretu Gracjana i jego diktów. Stąd spotykamy $\mathrm{u}$ nich dłuższe wywody na temat prawa naturalnego i objawionego i z nimi związanej racjonalności, natomiast krótsze odnośnie ldwóch pierwszych podstawowych elementów, mimo, że glossatorzy właśnie $w$ tych punktach nagromadzili już byli dużo materiału i teoretycznych ujęć. Rzecz przy tym znamienna, że dekretyści, mając już dostęp do Zbiorów justyniańskich, a więc i do autentycznego fragmentu D. 1, 3, 32, nadal podtrzymywali ograniczoną skuteczność prawa zwyczajowego po myśli konstytucji Konstantyna. Na ldowód, że ów fragment z Digestów był imb znany, możnaby przytoczyć ich definicje na ius consuetudinis względnie consuetudinarium, oparte właśnie na tym fragmencie ${ }^{22}$.

20 Zob. Genzmer, Die just. Kodifik.; Tenże Vorbilder für die Distinktionen der Glossatoren, Acta Congressus Internationalis Romae (1934) V. I, 343-358; K ut tn er, j. w.

21 B rie, j. w., 63 nst.

22 Jako znamienną rzecz należy zaznaczyć, że fragment ten dostał się do Dekretu Gracjana z interpolowanym dodatkiem: nisi legi sunt adversi, dodatkiem podporządkującym treść tego fragmentu konsty- 
Zanim przejdziemy do dekretalistów, musimy sobie najpierw zdać sprawe, czy i o ile pogracjanowskie Zwody prawa kanonicznego wniosły coś nowego do dotychczasowej struktury prawa zwyczajowego. W odpowiedzi na to pytanie nauka przytacza następujące dwa źródła: Pierwsze to konstytucja Grzegorza IX - Quum tanto sint grandiora peccata, quanto diutius infelicem animam detinent alligatam, nemo sanae mentis intelligit, naturali iuri, cuius transgressio periculum salutis inducit, quacunque consuetudine, quae dicenda est verius in hac parte corruptela, posse aliquatenus derogari. Licet etiam longaevae consuetudinis non sit vilis auctoritas, non tamen est usque adeo valitura, ut vel iuri positivo debeat praeiudicium generare, nisi fuerit rationabilis et legitime praescripta c. 11 $X$ 1,4). Drugie to dekretal Bonifacego VIII - licet Romanus Pontifex, qui iura omnia in scrinio pectoris sui censetur habere, constitutionem condendo posteriorem, priorem, quamvis de ipsa mentionem non facit, revocare noscatur; quia tamen locorum specialium et personarum singularium consuetudines et statuta, quum sint facti et in facto consistant, potest probabilius ignorare: ipsis, 'dum tamen sint rationabilia, per constitutionem a se noviter editam, nisi expresse caveatur in ipsa non intelligitur in aliquo derogare (c. 1 in VI 1,2).

Chyba nie trudno zauważyć, co nowego wnoszą do naszego zagadnienia oba te źródła.

Przede wszystkim stwierdzić należy, że Grzegorz IX zmienił $w$ formie ogólnej konstytucji dotychczasowe stanowisko Kościoła w sprawie nieskuteczności prawa zwyczajowego w przypadku consuetudo: contra ius (scriptum) positivum. Mówimy: w formie ogólnej konstytucji, bo w formie dekretału zaczął przełamywać owo stare stanowisko już Innocenty III, a nawet i sam Grzegorz IX ${ }^{23}$. Biorąc rzecz od strony praw-

tucji Konstantyna. O stosunku źródeł prawa rzymskiego do Dekretu Gracjana zob: Vetulani A., Revue historique de droit francais t étranger IV 16 (1937), 461-479, 674-692.

$23 \mathrm{~W}$ tym właśnie nowym kierunku odezwały się już były głosy takich kanonistów, jak Rufinus, Stephanus Thornacensis, Joannes Theutonicus - zob. M i chiels, Normae, 24-25. 
no-formalnej, możnaby się zapytać, czy do zaznaczenia owego nowego stanowiska nie wystarczyły przytoczone $w$ Zbiorze Grzegorza IX dekretały. Otóż nie mogły one wystarczyć, gdyż zacisnęlyby całe zagadnienie tylko do specyficznych, przez te dekretały poruszonych, przypadków. Zresztą, jak wskazuje treść tej konstytucji, chơdziło Grzegorzowi IX nie tylko o samo uogólnienie, ale równocześnie o podkreślenie, że prawo zwyczajowe może zwyciężyć ustawnicze tylko wtedy, gdy będzie rationabilis et legitime praescripta (consuetudo). Uzyskane powyższe stwierdzenia są o tyle jeszcze ważne dla naszych badań, że mogą rzucić światło na roztrząsane w nauce pytanie $w$ sprawie samej genezy tego bądź co bądź niezwykłego kroku obu papieży. Zdaniem naszym, zadecydowały tu nie tyle - jak chce Brie $^{24}$ - świadomość centralistycznej władzy papieskiej i pogląd legistów, iż prawo ustawnicze mogło by być uchylone przez zwyczajowe tylko principe sciente et consentiente, a więc poglądy prawno-teoretyczne, ile potrzeby bieżącego życia kościelnego, czyli przyczyny natury faktycznej, dekretałowej. Nie wdając się $w$ dalsze dociekanie, która $z$ innych przyczyn mogła tu wchodzic $w$ rachubę, w każdym razie wykluczamy, aby nią mogło być przeświadczenie legistów czy kanonistów, iż takim właśnie był pogląd justyniańskiego prawa. Innymi słowy, nieświadomą zbieżność poglądu. Innocentego III i Grzegorza IX z poglądem justyniańskim należy - zdaniem naszym - skwalifikować jako niezwykłe prawno-historyczne zjawisko.

Przechodząc do omówienia rozstrzygnięcia Bonifacego VIII, zawartego $\mathrm{w}$ przytocznym drugim źródle, już na pierwszy rzut oka zauważamy, że sprowadza się ono do zaznaczenia, iż nie traci swojej skuteczności partykularne prawo zwyczajowe $\mathrm{w}$ przypadku, gdy przeciw niemu pojawi się konstytucja papieska bez wyraźnej klauzuli znoszącej to prawo. Czyż to nowość? Niewątpliwie. Legiści w oparciu o D. 47, 12, 3,5 rozbudowali sobie wprost przeciwny pogląd. Za nimi poszli kanoniści. Że tego rodzaju pogląd był wyrazem centralistycznych

24 Brie, j. w. 92 nst. 
idei cesarzy i papieży, nie trzeba chyba uzasadniać. To też słusznie Brie $^{25}$ zauważa, że podziwiać należy owo odmienne rozstrzygnięcie Bonifacego VIII. Zdaniem tego autora wpłynęły na to rozstrzygnięcie nie tyle przytoczone przez papieża kryteria prawno-teoretyczne, ile konieczności natury praktycznej. Stąd - oto dalszy jego wywód - zajęte w tym punkcie przez Bonifacego VIII nowe stanowisko należy uważać za uzupełnienie przychylnego wobec prawa zwycźajowego odhiesienia się Innocentego III i Grzegorza IX. Do tych syntetycznych ujęć Brie'go pozwolimy sobie dodać następujące własne: Mianowicie przez to, że oba te postanowienia papieskie poszerzyły skuteczność kanonicznego prawa zwyczajowego, oddzieliły tym samym jeszcze bardziej dalszy jego rozwój od wpływów średniowiecznego prawa rzymskiego do takiego stopnia, iż odtąd można już całkiem śmiało mówić o samodzielnej kanonistycznej problematyce tego prawa.

d) Dekretaliści.

Jeżeli się mówi, że dopiero poglossatorzy stworzyli pełną teorię rzymskiego prawa zwyczajowego, to tymbardziej trzeba powiedzieć o dekretalistach $\mathrm{w}$ stosunku do kanonistycznego prawa zwyczajowego. Oto, jak w systematycznym zestawieniu wyglądała dekretalistyczna doktryna:

Zacznijmy od zewnętrznego elementu zwyczajowego.

Źe zwyczaj i prawo zwyczajowe jest dziełem danej prawotwórczej społeczności, sprawa ta nie ulega żadnemu wątpieniu. W ślad za prawem rzymskim, rozróżniającym consuetudines generales populi Romani względnie urbis Romae i speciales aliorum populorum, terrarum, civitatum municipiorum, oppidorum, locorum, poszedł Kościół: consuetudines universae Ecclesiae, Ecclesiae Romanae, terrarum (np. terrae Alemaniae, regni Daciae), ecclesiae metropolitanae vel aliarum circumpositarum, civitatis, municipii, locorum. Prócz tych wymieniają źródła kanoniczne consuetudines paroeciae, xenodochiorum, monasteriorum, capituli cathedralis, c. colegialis, prae-

25 Zob. Miechiels, Normae, 90. 
latorum, beneficiatorum, regularium, parochorum ${ }^{26}$. Nie będziemy tu wchodzili $w$ dociekanie, jak w dziejach każdej z tych społeczeności kształtowała się ich struktura prawna, zanim doszło do teoretycznego ujęcia przez Innocentego IV ich specyficznej osobowości prawnej. Zaznaczymy tylko, że co się tyczy ich podmiotowej zdolności tworzenia prawa zwyczajowego, to rozróżniano: isamodzielnie, czyli bez konsensu nadrzędnej władzy, mogly poza przypadkiem consuetudinis contra legem tworzyć prawo zwyczajowe tylko te, którym przysługiwała władza uchwalania obiektywnego prawa ustawniczego: reszta zaś spoleczności, czy to rządzących się autonomicznie, jak kapituły, czy to reprezentujących tylko pewne stany, jak zakonników, prałatów, beneficiatów, $z$ powodu braku jurysdykcji nie mogła bez zgody władzy nadrzędnej wytworzyć żadnego prawa zwyczajowego, a więc ani praeter ani secundum legem. Sam zaś fakt poszerzenia podmiotów zwycząjotwórczych z jurysdykcyjnych na niejurysdykcyjne nie powinien nikogo dziwić $\mathrm{w}$ średniowieczu, ponieważ płynna była granica w tym czasie między prawem obiektywnym i subiektwnym, prawem zwyczajowym a statutami względnie przywilejami ${ }^{27}$. Szkoda, że zagadnienie to nie zostało jeszcze w nauce - jak dotąd - dokładnie opracowane.

Jak przy tak szeroko rozbudowanej grupie podmiotów ujmowali dekretaliści sam zwyczaj? Otóż stweirdzić przychodzi, że w tym punkcie nie spotyka się $u$ nich jakichś głębszych dociekań, a tym bardziej śladu nawiązywania do genetycznych ujęć, które - jak wykazaliśmy na początku stworzyła myśl grecka. Ich skąpe wypowiedzi obracają się około postulatu zaistnienia na przestrzeni danego okresu czasu takiego stanu faktycznego.W' życiu społeczności, który mógłby być wyrazem zdecy'dowanej jej zbiorowej woli, skierowanym na zaistnienie niepisanej normy prawnej. Oczywi-

26 Zob. Köstler R., Consuetudo legitime praescripta, SZ Kan. Abt. 39 (1918) 154 nst.

27 Te wyrażenia J. Teutonika i Bernarda z Parmii przytaczamy za Michie ls e m, Normae. 87. 
ście tego rodzaju stan nie może się składać z jednorazowego zachowania się danej społeczności, bo wtedy pokrywałby się z aktem głosowania. Tu chodzi o danie wyrazu zbiorowej woli milczącej (= tacitus consensus populi). Aby ten wyraz mógł zrównoważyć głosowanie, musiał być powtórzony tyle razy w tym samym kształcie, aż stał się nawykiem i przeszedł próbę swej wytrzymałości na przestrzeni jakiegoś dłuższego czasu. Ale byłby $w$ błędzie, kto by myślał, że tego rodzaju ujęcie zwyczaju jest dorobkiem dopiero poglossatorskiej czy dekretalistycznej myśli teoretyczno-prawnej. Miał je już - jak wykazaliśmy - klasyczny prawnik rzymski, a przed nim grecki filozof. Zdaniem naszym takie właśnie ujęcie musialo w swych głównych zarysach wystąpić w każdej większej społeczności, gdy przyszło jej sięgać do źródeł własnego prawa pozytywnego. I tym właśnie tłumaczymy sobie $u$ średniowiecznych legistów i kanonistów owe skąpstwo $w$ wypowiedziach właśnie na ten temat $\mathrm{z}$ jednej strony a przeniesienie punktu ciężkości prawno-teoretycznych zainteresowań raczej na uściślanie poszczególnych wymogów i uzależnianie od nich zaistnienia prawa zwyczajowego.

Co się zaś tyczy owych poszczególnych wymogów, to dekretaliści sprowadzali je zazwyczaj do następujących: requiritur, quod (consuetudo) rationabílis sit et quo sit praescripta..., quod ex certa scientia non per errorem sit inducta..., et sciente illo, qui potest ius condere..., et quod sit tale ius, quod possit praescribi..., quod non sit contra ius naturale..., quod sit obtenta in contradictorio iudicio..., quod intendas sive credas te ius habere et ut in posterum id facias..., quod maior pars populi usa sit ea consuetudine ${ }^{28}$. Nie będziemy tu bliżej wchodzili $w$ genezę każdego $z$ wymienionych wymogów. Zaznaczymy tylko, że większość $z$ nich tkwi swymi korzeniami $\mathrm{w}$ teoretycznym dorobku legistów, a resztá jest mniej lub więcej wyłącznym dziełem kanonistyki.

Do tej ostatniej grupy należy $w$ pierwszym rzędzie zaliczyć przez wymienionych wyżej papieży wprowadzony wymóg: quod sit legitime (canonice) praescripta. Że przed wprowadzeniem tego wymogu Kościół posługiwał się wziętym $z$ pra- 
wa rzymskiego ogólnikowym określnikiem czasowym: consuetudo longa, diuturna, inveterata, vetusta, ta rzecz nie ulega żadnemu wątpieniu. Nierozwiązanymi dla nauki zostały natomiast zagaldnienia, co wpłynęło na wprowadzenie tego nowego wymogu i jaki jest jego sens prawny. Odpowiedź na pierwsze pytanie daliśmy już wyżej. Do rozpatrzenia zostało jeszcze pytanie drugie.

Zacznijmy od stwierdzenia, że pierwsze pokolenia dekretalistów (np. I. Teutonicus, B. Parmensis, Hostiensis, Innocentius IV, G. Durantis) wzięły ten określnik legitime (caninice) praescripta $\mathrm{w}$ znaczeniu dosłownym, czyli do państwowoprawnej sfery przeniosły instytucje prawa prywatnego, dotyczącą jednego ze sposobów nabycia prawa własności względnie ograniczonych uprawnień rzeczowych na rzeczy cudzej. To niezwykle prawno-historyczne zjawisko tłumaczy Köstler ${ }^{28}$ z jednej strony specyficzną strukturą kościelnych urzędów, łączących $w$ sobie prawno publiczne elementy $z$ prawno prywatnymi, $z$ drugiej zaś mieszaniem jeszcze $w$ tych czasach prawa obiektywnego $\mathrm{z}$ subiektwnym, zwłaszcza $\mathrm{w}$ przywilejach. Trudno nie przyznać słuszności temu tłumaczeniu. Co więcej. Ono, zdaniem naszym, pozwala zrozumieć, dlaczego następne pokolenia dekretalistów $w$ miare wzrastania $u$ nich prawno teoretycznej świadomości o przewadze obiektywnego charakteru prawa zwyczajowego wysuwają w swoich dociekaniach ten właśnie element normatywny jako przedmiot „zasiedzenia", a nie z tego elementu wynikające prawa podmiotowe. Przy takim stanie rzeczy nie da się zaprzeczyć, że u tych ostatnich dekretalistów mamy już do czynienia $z$ daleką ewolucją kanonistycznej myśli, która już nie będzie przyznawała zasiedzeniu prawa zwyczajowego. znaczenia prawno prywatnej instytucji, ale owo wyrażenie quod sit legitime (canonice) praescripta sprowadziła tylko do 40-letniego trwania danego zwyczaju, czasokresu, którym się posługiwało prawo rzymskie przy przedawnianiu przeciw Kościołowi, a który do 
„zasiedzenia" prawa zwyczajowego wciągnął, zdaje się poraz pierwszy, Innocenty III $^{29}$.

Jako drugi, szerzej przez dekretalistów rozbudowany wymóg uchodzi w nauce tacitus consensus populi.

Gdy idzie o samą zewnętrzną stronę tego konsensu, czyli objawiania go przez zwyczaj, to zarówno legiści jak i dekretaliści przyjmowali, że wyrażenia najstarszych źródeł: tacitus consensus omnium (D. 1, 3, 32) populi Romani, urbis Romae, populi Dei (Augustyn) byly użyte w znaczeniu państwowo-prawnym, zaczym oznaczały one przez analogię do grupy obywateli uprawnionych do głosowania nad daną ustawą, tylko czlonków prawnie uzdolnionych do wytwarzania zwyczaju w danej spoleczności. Ponieważ przy glosowaniu decydowała większość, stąd przy tworzeniu zwyczaju nie domagano się konsensu wszystkich; wystarczał konsens większości .Co więcej. Wobec starego poglądu, że uprawnienia prawotwórcze przeszly $z$ czasem na senat $i \mathrm{w}$ końcu na cesarzy, wysnuto wniosek, iż przy zwyczajo-twórczym konsensie wystarczy, gdy się wypowiedzą reprezentacyjne organa danej spoleczności, np. z okazji jakiegoś sporu (in contradictorio iudicio). Tyle o stronie zewnętrznej taciti consensus.

Bardziej skomplikowana była jego strona wewnętrzna. Na początek wistępna uwaga: Ponieważ — jak już wyżej zaznaczyliśmy - starożytna myśl grecka a za nią i rzymska sprowadzała wszystkie czynności psychiczne li tylko do funkcji rozumu (monizm psychologiczny), stąd wszelki wewnętrzny konsens, a więc i w naszym przypadku zwyczajo-twórczy. był uznawany nie za funkcje (nie znano jeszcze woli jako osobnej władzy duszy), ale rozumu. Gdy rozpoznanie woli jako odrębnej władzy dojrzało i astatecznie ustaliło się na podatnym gruncie mentalności rzymskiej, a w szczególności chrze-

29 Zna ten czasokres już Compilatio I, Lib. II Tit. 18 c. 5: Gregorius... Hortamus ergo ut praedicta loca... quae in lite sunt praesentia iure terminari faciatis XL tantum annorum ab utraque parte praescriptione servata. Zob. Quinque Compilationes Antiquae ed. Friedberg Wyrażenie zaś praescribere spotykamy już u Tertuliana - zob. wyżej 9.

frawo Kanoniczne -21 
ścijańskiej (Aubustyn) ${ }^{30}$, tym samym i konsens prawo twórczy został wydzielony $z$ rozumu i związany $z$ wolą. Mówiąc o konsensie, że został wydzielony z rozumu, nie chcemy przez to powiedzieć, że zupelnie zostal wyjęty $z$ pod oddzialywania tej władzy. Przeciwnie. Gdy bliżej przypatrzymy się na ten temat wypowiedzianym wywodom Tomasza $z$ Akwinu, staniemy przed ciekawym dla naszych badań zjawiskiem. Oto one: Omnis lex proficiscitur a ratione et voluntate legislatoris... lex autem humana a voluntate hominis ratione regulata (Summa theolog. II 1 Qu. XCVII art. 3). Jaka zaś jest rola rozumu w tym akcie, odpowiedział Tomasz w osobnym artykule: Utrum lex sit aliquid rationis: ad legem pertinet praecipere, et prohibere: ised imperare est rationis... praesupposito tamen actu voluntatis... Imperare autem est quidem essentialiter actus rationis: imperans enim ordinat eum, cui imperat, ad aliquid agendum... quod lex quaedam regula est, et mensura actuum, secundum quam inducitur aliquis ad egendum: regula autem et mensura humanorm actuum est ratio, quae est principium primum actuum humanorum: rationis est ordinare ad finem, qui est primum principium in agendis... quod sicut in actibus exterioribus est considerare operationem et operatum..., ita in operibus rationis est considerare ipsum actum rationis, qui est intelligere et ratiocinari, et aliquid per huiusmodi actum constitutum... et quia ratio etiam practica utitur quodam syllogismo in operabilibus... . ideo est invenire aliquid in ratione practica, quod ita se habeat ad operationes, sicut se habet propositio in ratione speculativa ad conclusiones... quod ratio habet vim movendi a voluntate... ex hoc enim quod aliquis vult finem, ratio imperat de his quae sunt ad finem; sed voluntas de his quae imperantur, ad hoc quod legis rationem habet, oportet quod sit aliqua ratione regulata: et hoc modo intelligitur, guod voluntas pro his habet vigorem legis: alioquin voluntas principis magis esset iniquitas, quam lex (Summa teeol. II $1 \mathrm{Qu}$. XC art. 1; Ibid. Qu. 17, art. 1:

30 Zob. Po hlenz M., Der hellenistische Mensch, Göttingen, 1929 Tenże DieStoa, 61 nst. 
Utrum imperare sit actus voluntatis vel rationis). Że zaś wszystkie te wywody należy odnieść także do prawa zwyczajowego wynika z Summa theol. II 1 Qu. XCVII art. 3: Utrum consuetudo possit obtinere vim legis, gdzie czytamy: sicut autem ratio et voluntas manifestantur verbo in rebus agendis, ita etiam manifestantur facto... unde etiam et per actus maxime multiplicatos, qui consuetudinem efficiunt... inquantum scilicet per exteriores actus multiplicatos interior voluntatis motus, et rationis conceptus efficacissime declaretur. Streszczając krótko wszystkie te wypowiedzi Tomasza z Akwinu dochodzimy do wniosku, że pokolenia dekretalistów a nawet legistów, mając przed oczyma owe wywody, musiały przy rozpatrywaniu wewnętrznej strony zwyczajo-twórczego konsensu brać pod uwagę nie tylko jego stosunek do woli, ale i do rozumu. Mówimy; że do rozumu nie dlatego, iż regula in mensura, owe konstytutywne elementy każdego prawa, są tworem tej właśnie władzy psychicznej, bo te elementy mutatis mutandis rozum do każdego czynu ludzkiego, ale dlatego, że imperare (= dictamen practicae rationis - Summa theol. II $1 \mathrm{Qu}$. XCI art. 3), ów specyficzny składnik każdego prawa, należy $z$ istoty swojej do rozumu.

Po tej wstępnej uwadze przejdźmy do odpowiedzi na pytanie, jak w ówczesnych czasach nauka kanonistyczna określała bliżej stosunek zwyczajotwórczego konsensu do rozumu i woli.

Otóż w stosunku do rozumu domagała się ona, aby ten konsens był dokonany, jak się wyraża glossa ord. ad c. $11 \mathrm{XI}, 4$ : quod ex certa scientia, non per errorem sit (consuetudo) inducta $i$ to na ogól pod sankcją niezaistnienia takiego prawa zwyczajowego. Mówimy: na ogól, bo jakkolwiek D. 2, 1, 15 mówi: quid tam contrarium consensui est quam error, musial być wzięty za podstawę do rozstrzygnięcia niejasny fragment D. $1,3,39$, co dało legistom średniowięcznym i za nimi kroczącym dekretalistom asumpt do rozróżniania błędów i w zależności od danej ich grupy do rozmaitego ustosunkowania się $\mathrm{w}$ sprawie wpływu błędu na zaistnienie prawa zwyczajowego, zwłaszcza w przypadku consuetudo contra legem. Na równi 
z powyższym, szeroko dyskutowanym i nierozstrzygniętym, zagadnieniem o mawiali dekretaliści potrzebę dobrej wiary. W stosunku zaś do woli wysunęly dekretalistyka i filozofia ówczesna postulat, aby zwyczajotwórcze działanie poszczególnych członków danej spoleczności nie odbywalo się pod przymusem, ani fizycznym ani moralnym. $Z$ tego nie wynika, aby musiało ono być zupelnie dobrowolne. $\mathrm{Z}$ przytoczonych wyżej wywodów Tomasza z Akwinu widać niedwuznacznie, że imperare względnie dictamen rationis practicae nie jest czymś obojętnym przy powstawaniu prawa czy to ustawniczego czy to zwyczajowego. Wprawdzie taki rozkaz względnie zakaz nie odbiera wolności woli, ale nie ulega wątpieniu, że swoją siłą duchową oddziaływa na nią ograniczająco. Slowem, staje się dla woli motywem na podobieństwo strachu, wywołanego jakąśs groźbą. Poza tymi dwoma warunkami, które mają towarzyszyć woli przy dokonywaniu przez nią konsensu, żądali kanoniści jak i legiści, aby populus - a więc członkowie danej spoleczności wzięci nie jako singuli lecz jako universi - działal $\mathrm{w}$ zamiarze wprowadzenia prawa zwyczajowego: eo animo ut sit consuetudo deinceps - Gl. ad D. 1, 3 , 32; ut habeat..., et animum inducendi consuetudinem Innoc. IV Apparatus Tit. 4, lib. I, n. 4. Mówiąc o potrzebie takiego zamiaru nie sposób nie zauważyć, że jakkolwiek nie miała ona wyraźnego uzasadnienia w źródłach prawa rzymskiego i kanonicznego, była jednak przez naukę prawa ujmowana jako najważniejszy wewnętrzny wymóg zwyczajotwórczej zbiorowej woli danej spoleczności. Jeżeli zaś idzie o dyskusję i różnicę zdań przy tym wymogu, to występowały one raczej tylko przy ustalaniu kryteriów rozpoznawczych istnienia takiego zamiaru. Gdy bowiem jedni poprzestawali na notoryczności faktycznej, drudzy domagali się jurydycznej, w szczególności by była dokonana in iudicio contradictorio.

Zostal nam jeszcze do omówienia ostatni wymóg - rationabilitas. Jak wiadomo, dotyczy on przedmiotu, czyli inaczej, samej treści prawa zwyczajowego. Nawiązując do tego, co dotąd na ten temat już wyżej powiedzieliśmy, stwierdzić nam przychodzi, że gidy wywody legistów $z$ powodu braku bodź- 
ców źródłowych musiały utknąć na martwym punkcie, to dociekanie dekretalistów po potężnym „zastrzyku” w postaci rozlicznych dekretów papieskich, a zwłaszcza wyżej przytoczonej konstytucji Grzegorza IX powiększyły wybitne negatywny zasięg tego kwalifikatora. Wobec dokładnego wyliczenia przypadków irrationabilitatis przez Michielsa ${ }^{31}$, wyliczenia przewyższającego przypadki podane w aparacie źródłowym Gasparri'ego przy kanonie 27 C. I. C., uważamy za zbyteczne je tutaj przytaczać, a tym bardziej analizować. Zaznaczymy tylko, że ich zasięg objął poza nietykalnością boskiego prawa naturalnego i pozytywnego jeszcze pokaźną liczbą zastrzeżeń ściśle kościelnych.

Gdy zaś idzie o teoretyczno prawne ujęcie tego kwalifikatora od strony pozytywnej, to poza wyżej przytoczonymi wypowiedziami na ten temat Tomasza z Akwinu oraz jego postulatem, by przy tworzeniu prawa ustawniczego i zwyczajowego miało się na oku przede wszystkim dobro ogólne (Summa Theol. II 1 Qu. XC art. 2, Qu. XCV art. 3), w tej sprawie właściwie już nic więcej nie przybyło.

Wszystko, co dotąd powiedzieliśmy o prawno-teoretycznych poglądach dekretalistów na temat kanonicznego prawa zwyczajowego, byłoby niezupełne, gdybyśmy pominęli roztrząsane przez nich pytanie, czy i o ile do zaistnienia danego prawa zwyczajowego $w$ kościele jest jeszcze potrzebny udział najwyższej władzy.

Zanim przejdziemy do odpowiedzi dekretalistów na to pytanie, zdajmy sobie sprawę ze stanowiska, jakie $w$ tym punkcie zajęło było prawo rzymskie. Otóż według naszych wstępnych dociekań te prawa zwyczajowe ,które powstały u Rzymian przed zaistnieniem ich państwowości, były dziełem li tylko konsensu ich przedpaństwowej społeczności. Z chwilą zaś pojawienia się państwowości musiało siłą rzeczy przyjść po raz pierwszy do ustosunkowania isię najwyższej władzy rzymskiej zarówno do dawniejszych praw zwyczajowych jak

s1 Michiels, Normae, 138 nst. 
i do przyszłych. W następstwie tego ustosunkowania doszło do podziału prawa zwyczajowego na secundum, praeter i contra legem. Sledząc na podstawie zachowanych źródeł dalszy rozwój tych trzech rodzaji prawa zwyczajowego, stwierdziliśmy, że przy dwóch pierwszych rodzajach zostawiło prawo rzymskie nadal konsens danej społeczności jako jedyną, bezpośrednią przyczynę zaistnienia prawa zwyczajowego, natomiast przy trzecim rodzaju, t.j. przy consuetudo contra legem stworzyło skomplikowane zagadnienie. Zagadnienie to zostało z czasem przez glossatorów i poglossatorów rozwiązane następująco: Aby prawo zwyczajowe mogło skutecznie usunąc prawo ustawnicze, musi do konsensu danej społeczności dołączyć się jeszcze przynajmniej tacitus consensus najwyższej wladzy państwowej $\mathrm{w}$ charakterze principe sciente et consensum prebente lub per patientiam principis permittentis uti aliqua consuetudine. $\mathrm{Na}$ zasadzie jakich kryteriów doszli legiści do takiego właśnie rozwiązania, a więc czy n.p. z tytułu - jak chce Brie ${ }^{32}$ - fikcji prawnej o przelaniu takiej władzy przez rzvmski lud na cesarzy, czy wyższości prawa pisanego nad niepisanym, trudno rozstrzygnąc. W każdym razie między źródlami prawa rzymskiego nie spotkaliśmy takiego, na które możnaby się było powolać.

I oto rzecz wielce znamienna. Na tym samym stanowisku, które zajęli legiści, stanęli zasadniczo dekretyści i dekretaliści. Mówimy: zasadniczo, bo że tu i ówdzie odezwał się głos, kwalifikujący wyżej rolę konsensu najwyższego czynnika koscielnego, jak n.p.: quod sit de scientia principis inducta non tantum de tolerantia ( $\mathrm{J}$. Theutonicus); quod non potest abrogare nisi per expressum consensum Paoae (idem); tacito consensu videtur eam (consuetudinem) confirmare (Hugucio); si vero multitudo non habeat liberam potestatem condendi sihi legem, vel legem a superiore potestate positam removendi, tamen ipsa consuetudo in tali multitudine praevalens obtinet vim legis, in guantum per eos toleratur, ad quos pertinet multitudini legem imponere: ex hoc enim ipso videntur 
approbare, quod consuetudo introduxit (Tomasz $z$ Akwinu), nie naruszyło to bynajmniej ogólnie $w$ tym czasie panującego przeświadczenia, że $\mathrm{w}$ przypaldku consuetudo contra legem dana spoleczność przestała być wlaściwą przyczyną zaistnienia prawa zwyczajowego.

Gdy $z$ powyższymi osiągnięciami przychodzi nam $z$ kolei wkraczać $w$ następny i zarazem ostatni prawno-historyczny okres naszych badań, t.j. w kanonistykę podekretalistyczną, sięgającą aż do czasu pojawienia się obowiązującego dzisiaj kodeksu prawa kanonicznego, zdajemy sobie dobrze sprawę $z$ obowiązku, że powinnoby się na ten końcowy etap zwrócić jaknajbaczniejszą uwagę, gdyż on właśnie jako graniczący bezpośrednio z C. I. C mógł najsilniej oddziałać na twórców tytułu II księgi pierwszej De consuetudine. Jednak ze względu na wąskie ramy tego artykułu musimy zrezygnować $\mathrm{z}$ szerszego omówienia problematyki prawa zwyczajowego $w$ tym okresie czasu i ograniczyć się tylko do skrótów.

Jako pierwiszą zmianę $\mathrm{i}$ to zasalniczą, której na przestrzeni tego czasu (w. XVI - XIX) dokonano odnośnie bezpośredniej przyczyny zaistnienia kanonicznego prawa zwyczajowego, należy wymienić przeniesienie punktu ciężkości $z$ konsensu danej społeczności na wyłączny konsens odnośnej władzy wyższej. Gdy zaś idzie o podanie powodu tej zmiany, to niestety - jak dotąd - nie spotkaliśmy na to pytanie pełnej odpowiedzi. Wprawdzie Michiels ${ }^{33}$ w swoich dociekaniach próbuje wykazać, że takie właśnie stanowisko zajmował już Kościół od czasów Grzegorza Wielkiego i że tylko odmienny pogląd glossatorów i poglossatorów prawa rzymskiego opanował swoim wpływem myśl kanonistyczną aż do schyłku średniowiecza, ale wywód ten, zdaniem naszym, jest pozbawiony

s3 M i che $1 \mathrm{~s}$, Normae, 30 nst. 
siły dowodowej. Przytoczone bowiem powiedzenia Grzegorza W., Miko'aja I i Leona IX, jak już zaznaczyliśmy wyżej, dotyczą zupełnie innego zagadnienia. Mianowicie z jednej strony wykreślają one granicę, której kościelne prawo zwyczajowe przekroczyć nie może, $\mathrm{z}$ drugiej zaś temu prawu przyznają w całej pełni wiążące znaczenie. Nie zapominajmy, że Kościół nie mial przed swoim zaistnieniem żadnego prawa zwyczajowego, to też $z$ chwilą gdy ono na wzór świecki zaczęło się w nim pojawiać, musial - podobnie jak to uczyniło państwo rzymskie - także i on do tego prawa się ustosunkować. Że to ustosunkowanie odbyło się mutatis mutandis wedlug mordelu prawa rzymskiego, zarówno przedjustyniańskiego jak i ujmowanego przez średniowiecznych legistów, - rzecz ta chyba nie ulega żadnemu wątpieniu. Stąd, ponieważ państwo rzymskie uznało konsens danej własnej społeczności za główną przyczyne zaistnienia prawa zwyczajowego, nie dziwimy się, że i Kościół zaczął przyznawać taką samą zdolność prawną swoim społecznościom. I te właśnie pierwsze akty kościelne, uzrające pewne społeczności za podmioty zdolne do wytworzenia prawa zwyczajowego, zadecydowały $w$ naszym przeświadczeniu o tym, że odtąd zbędnym już się stało ponawianie tych aktów przy każdym poszczególnym przypadku. I jeżeli w którym przypadku owo zagadnienie dodatkowego aktu uznania ze strony władzy mogło wystąpić, to tylko przy consuetudo contra legem. Czy rzeczywiście w okresie przedjustyniańskim ono wystąpiło, trudno coś pewnego powiedzieć. Natomiast wiemy, że podjęli je średniowieczni legiści i kanoniści, gdy zażądali konsensu najwyższej władzy w charakterze aprobaty. Zapyta ktoś, więc dlaczego owa zmiana pojawiła się począwszy od wieku XVI, kiedy tego rodzaju stan prawny, potwierdzony ponadto wyżej przytoczoną konstytucją Grzegorza IX, powinien się byl dalej utrzymać. Otóż wydaje się nam, że odpowiedzi na to pytanie należy szukać nie gdzie indziej tylko w poglądowych zmianach, jakie od XIV w. zaczęly się pojawiać $\mathrm{w}$ stosunku do roli ludu w danym państwie. Wiadomo bowiem, jak ludowłacze prądy zaczęły wtedy uderzać silnie nie tylko $\mathrm{w}$ ustroje państwowe, ale $\mathrm{i} \mathrm{w}$ kościelny. Do- 
wodem: w górze koncyliarystyczne idee, w dole demokratyczne ruchy duchowieństwa niższego. Stąd, gdy z kolei przyszło w Kościele i poza Kościołem do reakcji przeciwko tym ideom i ruchom, reformistyczne czynniki nie tylko oczyścily sferę dogmatyczną od błędów heretyckich, ale sięgnąwszy do podstawowych założeń ustroju Kościoła zażądały ściślejszego podporządkowania się władzy papieskiej zarówno dyscyplinarnej jak i prawotwórczej. I tu właśnie zdaniem naszym należy szukać początku owego postulatu teologów i kanonistów, aby zaistnienie prawa zwyczajowego w Kościele uzależniać tylko od najwyszej władzy a nie od samej woli społeczności. Kryzys, który na tej przestrzeni czasu przechodziły korporacje ${ }^{34}$, mógł i najprawdopodobniej odegrał rolę dogodnej okazji do przeprowadzenia tej zmiany.

Powyższa zasadnicza zmiana pociągnęła za sobą siłą rzeczy drugą o tyle, że odebrawszy konsensowi danej społeczności charakter bezpośredniej przyczyny zaistnienia prawa zwyczajowego, tym samym zmieniła dotychczasową czynną podmiotowość tychże społeczności na bierną. Byłoby jednak błędem twierdzić, iż na skutek owej ,capitis diminutio" wszystkie społeczności spadły ido poziomu biernego podmiotu. Nietknięta bowiem została ich cała dotychczasowa działalność, ale z tym zastrzeżeniem, że odtąd będzie dawala w skutku nie - jak się wyraża kanonistyka - consuetudinem ut ius, lecz ut factum. Nie będziemy się tutaj wdawali w rozstrzącanie teoretyczne, jaką treść zawiera to techniczne ujęcie ut factum. W każdym bądź razie to pewne, że nie ogranicza się ono do samych elementów faktycznych zaistnienia danego zwyczaju, ale obejmuje także wewnętrzne. Co więcej. Zarówno jakość tych elementów i sposób posługiwania się nimi nie został pozostawiony do woli danej spoleczności kościelnej, lecz zdeterminowany dotychczasowymi normami prawnvmi, za wyjatkiem dwóch zmian: jednej, aby wymóg animus se obligandi był ogra-

$34 \mathrm{Gierke}$ O., Die Staats = und Korporationslehre des Alterthums und des Mittelalters, Berlin 1881, 501-644. 
niczony tylko do przypadku consuetudo praeter legem i drugiej, aby wymóg „zasiedzenia”, wprowadzony do przypadku consueturdo contra legem, był poszerzony do przypadku consuetudo praeter legem.

Stwierdzeniem powyższych zmian, dokonanych $w$ trzecim okresie czasu, zamykamy nasze uwagi nad calokształtem podstawowych elementów obowiązującego dziś kanonicznego prawa zwyczajowego. 